\title{
Employee retention at 'Precious' English language course in Surabaya
}

\section{Pemertahanan karyawan pada lembaga lursus bahasa Inggris 'Precious' di Surabaya}

\author{
Eddy Roesdiono ${ }^{1}$, Pinky Saptandari EP ${ }^{2}$, \& Dewi Retno Suminar ${ }^{3}$ \\ ${ }^{1}$ Department of Human Resource Development, Postgraduate School, Universitas Airlangga \\ ${ }^{2}$ Department of Anthropology, Faculty of Social and Political Sciences, Universitas Airlangga \\ ${ }^{3}$ Faculty of Psychology, Universitas Airlangga \\ Address: Jalan Airlangga 4-6, Surabaya, East Java 60286 \\ E-mail: eddyroes@gmail.com
}

\begin{abstract}
Employee retention is related to the ways in which an organization keeps its employees. Failure to maintain employee retention may lead to unfavorable issues that negatively affect an organization's performance. As a medium-sized organization, the Precious English Language training institution presents a unique state of employee retention in employing a balanced number of full-time and part-time teachers, most of whom have served at the institution between 10 and 29 years. The research on employee retention at Precious was conducted qualitatively and studied teachers who had served over ten years. The study also used other related artefacts to support findings. Semi-structured interviews were also conducted alongside observation of the teachers. The research results suggest that employee retention at Precious has been a natural result of the physically and emotionally favorable work environment that has arisen from the institution's effort to maintain excellent teaching methods and persistent organization culture. Such job satisfaction has led to open employee engagement which has further contributed to the organization's employee retention. The organization's nonexistence employee retention plan (that primarily uses non-financial rewards) has naturally led to increased employee retention alongside a drive to maintain the quality of the institution's teaching in English Language.
\end{abstract}

Keywords: employee retention; employee engagement; job satisfaction; non-financial rewards

\begin{abstract}
Abstrak
Pemertahanan karyawan berkaitan dengan bagaimana organisasi mempertahankan karyawan-karyawannya selama mungkin. Kegagalan organisasi untuk mempertahankan karyawan bisa mengarah kepada berbagai persoalan kinerja organisasi. Pemertahanan karyawan pada lembaga kursus bahasa Inggris Precious menunjukkan fakta unik karena lembaga pelatihan bahas Inggris kelas menengah tersebut, yang memperkerjakan jumlah berimbang antara karyawan full-timer dan karyawan part-timer berhasil mempertahankan sebagian besar guru-gurunya selama antara 10 sampai 29 tahun. Penelitian mengenai pemertahanan karyawan pada Precious dijalankan dengan metode kualitatif, dengan menggunakan guru yang memiliki masa kerja lebih dari sepuluh tahun sebagai partisipan berserta dengan artefak-artefak terkait lainnya untuk mendukung temuantemuan. Wawancara semi-terstruktur digunakan bersama dengan observasi yang diperlukan. Hasil penelitian menyiratkan bahwa pemertahanan karyawan pada Precious ternyata tidak dengan sengaja diupayakan dan terbentuknya pemertahanan karyawan pada Precious ada kaitannya dengan upaya lembaga tersebut untuk menjalankan meode pengajaran berkualitas, budaya organisasi yang terpelihara dan lingkungan kerja yang nyaman secara fisik dan emosional yang bersama-sama membentuk kepuasan kerja. Kepuasan kerja demikian ini pada akhirnya berkontribusi pada pemertahanan karyawan organisasi. Pemertahanan karyawan yang semula tidak direncakan telah berkembang secara alamiah menjadi pemertahanan karyawan nyata yang secara dominan terbentuk oleh imbalan-imbalan non-finansial dan upaya-upaya peningkatan kinerja professional pengajaran bahasa Inggris yang berjalan bersama dengan kesungguhan untuk memelihara kualitas sistem pengajaran bahasa Inggris.
\end{abstract}

Kata kunci: pemertahanan karyawan; employee engagement; kepuasan kerja; imbalan non-finansial

\section{Introduction}

Employee retention is defined as an organization's ability to ensure that their employees stay with the organization. A healthy and sustainable organization depends on retention of their key employees 
(Das \& Baruah 2013). Retention of the best professional employees is significant in reducing employee recruitment frequency and selection cost, as well as maintaining continuity of expertise and competition culture (Tymon Jr et al. 2011). Efforts for employee retention assure the best performance contribution from employees, which in turn will guarantee the company's sustainable operation. An organization's inability to formulate and implement strategies for the recruitment and retention of competent employees to reach organizational goals is the main reason behind a drop-in organization performance (Das \& Baruah 2013). In reality, employee retention is not always successful, and failure to retain employees leads to considerable losses. The United Kingdom, for instance, suffers a national loss of $£ 42$ billion (equivalent to $\mathrm{Rp} 630$ trillion) per year for failure to maintain employee retention (Thomas 2010).

Employee retention is associated with employee engagement which deals with aspects of employee's commitment, dedication, and performance. As a positive drive, personal engagement motivates and binds ties between employees and their organization in an emotional, cognitive, and physical way. Employee engagement is also described as measurement of an employee's energy and passion for their organization (Hughes \& Rog 2008). Engaged employees are individuals who take on real actions aimed at improving their organization's business. A study in America reveals that disengagement was responsible for a drop-in productivity costing between $\$ 287$ billion $\$ 370$ billion (USD) (Bandura \& Lyons 2014). No similar relevant data is available in Indonesia.

Some studies have contributed to factors that trigger the success of employee retention, yet such data has been obtained from studies conducted in large corporations. Employee retention and engagement issues within small and middle-sized firms and in specific industries remain unexplored. Aspects of employee retention and engagement among teachers as employees in middle-sized non-formal educational and training institutions form interesting issues owing to the fact that, for instance, English language training institutions have not been able to successfully retain their teachers. Employee retention in non-formal education institutions, such as that of an English language course, has not been widely explored in researches.

As the focus of this study, an English language training institution (identified as 'Precious' within this report for privacy reasons) based in Surabaya represents a certain significance in terms of employee retention. Established in 1985, this training institution has approximately 1,200 students registered over their five different schools. The English language training institution offers native Englishspeaking teachers (NEST) in three of their schools and non-native speaking teachers (local teachers) in two other schools. Out of the total 14 non-native speaking teachers, 10 have been working at Precious between 12 to 29 years which suggests a significant formation of employee retention. Understanding how the institution's non-native teachers have been retained for such a relatively long time can be a gateway to further understanding aspects of employee retention in commercial middle-sized organizations. This can also bring valuable insight and information about the way the employee retention has been formed and in the underlying factors that lead to such sustainable employee retention. The research questions are as follows: 1) How is employee retention at the 'Precious' English language course formed? and 2) Which factors play the dominating roles in such formation of employee retention?

\section{Research Method}

This research employs a qualitative method which provides ample opportunity for obtaining comprehensive data and information on employee retention reality. Data was collected by means of a case study model focusing on individuals, programs, and culture. Purposive sampling was used to select research participants. The participants included the owners of the institution and the local teachers who had worked for 'Precious' for over ten years. The owners were a married couple and the husband, a British native, could not participate in the research for time availability reasons. Of the total 14 local teachers, 10 had been in service between 12 and 29 years and thus were eligible for the research. Of the 10 local teachers, five taught full-time and five taught part-time. One fulltime teacher and one part-time teacher refused to participate in the research for personal reasons, 
and therefore only eight teachers participated. Primary data was collected through observation and both semi-structured and in-depth interviews with owner and local teachers. Semi-structured interviews were used to equip the researcher with guidelines to stay focused on the issues (Saebani 2015) while the in-depth interview, a type of interview that allows the researchers to understand the deeper meaning of the participant's life and experience (Raco 2010), was useful in obtaining a free flow of comprehensive information for better exploration of aspects of employee retention and employee engagement. Observation was conducted by observing the teacher's preparation activities, the teacher's interaction with other teachers, and workshop activities. Interviews and observation were also equipped with secondary data in the form of documentation and related artifacts such as course-files, flash-cards, realia, and other teaching aids. The teachers as participants in this study were identified as Participants A, B, C, D, E, F, G and H, and the owner was identified as Participant O.

\section{Result and Discussion}

\section{Employee retention structure at 'Precious'}

According to participant $\mathrm{O}$, employee retention at 'Precious' is not based around a planned, designed policy or strategy by the owners at the time it was established. Participant $\mathrm{O}$ said that she and her husband (identified as Mr. Good), a native speaking teacher and educator, originally wished to start an English language training institution that offered different teaching approaches and methods with different course materials benefitting from the Communicative Language Teaching (CLT) model. Therefore, to respond to this challenge, considerable efforts were made to improve the teachers' teaching quality and standards, including classroom teaching techniques and preparation of tailormade quality teaching materials and course files. Very few efforts, if any, were intentionally made to the making of employee retention strategy. Participant $O$ believed that it is the development of organizational characteristics that the institution provided that make the teachers stay, as quoted below:

“When we started 'Precious', Mr. Good and me did not ever think about any strategy to retain our teachers. If we now do have some teachers who have been staying here for such a long time, that may be a result of a natural retention process" (Participant $\mathrm{O}$ ).

The high employee retention at 'Precious' is somewhat contrary to the related theories, which suggest that the organization's ability to formulate and implement strategies capable of retaining competent employees to reach organizational goals is the major challenge to organization performance (Das \& Baruah 2013). Aguenza \& Som (2012, p 89) said that employers can improve employee retention and engagement by means of practical strategies that focus on people, programs covering a set of policies, and practices to create a convenient work atmosphere adjusted to the organization's mission, vision, culture, goals, and values.

\section{Challenging work}

All of the participants perceived the learning-teaching process at 'Precious' as challenging work. This started with the time they underwent their initial unpaid three-month training several years back. The teachers' daily challenge comes in the form of the necessity to update course files and to find and apply new classroom instruction ideas suitable for varying pupil ages and characteristics. Other challenges are in unique class situations which demand more than teaching skills, as shown in the following quote:

"Last term I had an autistic young student in my class. I found it difficult to make her stay put in class. She would run around the class, bothering her classmates. I thought I had to find a way...you see to calm her down. So, I gave her extra attention. I gave her good words on what she was wearing that day, things like that. I made a friendly eye contact and praised her anytime she did a good thing. In the long run, I managed to control her. She did better..." (Participant G, male, part-time).

This is supported by Walker (2001) who is of the view that the provision of challenging work is one factor that forms employee retention. 


\section{Opportunity to learn}

'Precious' has provided an ample opportunity for the teachers to learn and improve both their teaching skill and English language proficiency. Workshop sessions that are provided three times a term (lasting between 90 to 120 minutes) allow the teachers to receive and share new classroom teaching approaches and methods of speaking, listening, reading, writing, and other class actions. The presenter of workshop is usually the Director of Studies, either a native speaking teacher or a local teacher. The following shows how teachers perceive such learning opportunity:

"The regularly given workshop is really beneficial: the presenter shares his ideas that we can apply in our classes. You see, despite the fact that we have been teaching for long, we still need new and fresh classroom ideas...." (Participant E, female, part-time).

The opportunity to learn is also made available by means of discussion of teaching techniques or through course file delivery among teachers. Such opportunity is supported by Govaerts et al. (2010), who conclude in their research that a appreciative approach through learning and a positive work climate significantly impacts employee retention.

\section{Positive relations with co-workers}

Positive relations aimed at the local teachers at 'Precious' have been characterized with productively dynamic and a constructive atmosphere, despite their different religious (Islam and Christianity) and ethnic (Javanese, Chinese, and Batak) backgrounds. The following extract from an interview describes how good relations has been maintained among the teachers:

"The maghrib prayer time is close to the evening class break time which is only ten minutes. I know punctuality really matters here. But if strictly use the ten minutes allocation for break and praying, there won't be enough time. That's why I leave the class for break five minutes earlier. Co-workers who do not have to go praying never make a fuss on that, nor report it to the management as an unacceptable conduct" (Participant H, male, part-time, 27 years of service).

Teachers get along well during and outside of the workplace, with the exception of minor misunderstandings that do not usually last long. The positive and productive relationships among the teachers is considered as an internal harmony aspect that supports employee engagement (Anitha2014).

\section{Compensation, remuneration and performance appreciation}

Financial reward at 'Precious', though considered as 'not very big', is perceived as satisfactory by both full-time and part-time teachers. Full-time teachers receive a fixed monthly salary plus the so called ' $13^{\text {th }}$ salary' as a bonus upon completion of one-year term. Part-time teachers receive wages based on the teaching hours accumulated at the end of each month. Another benefit offered to the teachers is the waiver of fees for the children of full-time teachers, and an easier fee payment scheme for the children of part-time teachers. Appreciation is also shown in the form of assignments provided for the teachers, for instance for external teaching or interpreting jobs, all managed and under the permission of 'Precious'. The teacher satisfaction regarding compensation, remuneration, and appreciation is represented in the following quotes:

"My salary as a full-timer is not that big. But that's not a big deal. What is more important is the fact that my children can study English at 'Precious' for free..." (Participant D, male, full-time).

"I am happy with what I earn as a part-timer; it is not that bad. I have other earnings from other assignments, like being an examiner for University of Cambridge tests managed by 'Precious'...” (Participant B, female, part-time).

Employee satisfaction on both the financial and non-financial rewards was recognized by Anitha (2004) with the view that compensation and remuneration form a crucial role in shaping employee engagement, subsequently motivating employees to achieve and focus on personal development. 


\section{Employee performance and performance recognition}

There is no special system or formal pattern available for recognition of the local teachers' competence and performance other than the appointment of the role as Principal. The teachers' recognition and performance are mostly affirmed by the students and students' parents. Some of the participants have said it is normal for them to have the students request them again as teachers in the next classes, as detailed below:

"Very often I am asked to teach them next term. 'Next term' means two terms after the lapsed term as a teacher is not supposed to teach the same class in the following term. It has always been an honor to me to get 'reserved' for a class that will start six months ahead. Appreciations from parents who are happy with their children speaking ability are also the thing makes us proud and contented..." (Participant C, female, part-time).

In relation to this, Walker (2001) was of the view that supervisors, team members, co-workers, and customer recognition increases the feeling of being appreciated, which in turn leads to employee loyalty to the organization.

\section{Work-life balance}

The work-life balance made available at 'Precious' has been perceived as beneficial, especially to the part-timer staff, as this provides them with more personal time. Work-life balance for the fulltime staff is also pleasant with the absence of strict office hours; classes begin at 14:00 and finish at 21:00, allowing the staff to have the morning and early afternoon to themselves. The work-life balance scheme at 'Precious' has been appreciated by the staff, shown below in the response of two interviewees:

"I am comfortable being a part-timer; I get cash that I need while I still have the time to take my parents to the hospital for routine healthcare service. I also have the time to prepare dinner for my family..." (Participant B, female, part-time).

"I am a full-timer, but it is possible for me to leave the office in the afternoon to pick up my kids at school or have lunch at home..." (Participant G, male, full-timer.

Deery \& Jago (2015) in their research conclude that in order to achieve a high level of employee retention, it is necessary for the organization to implement employment policies in favor of the staff. Another study based in England added to the view that the intervention of work demand into an employee's personal life (such as working during weekends) leads to employee's stress and other emotional issues (Hyman \& Summers 2004).

\section{Good communications}

For the purpose of exploration of the existence of quality communications related to employee retention within the organization, communications between the owner and the teachers at 'Precious' is highlighted. These communications can be as formal as negotiations on employee schemes, or as casual as personal matters, as represented by the following two extracts of interview:

\footnotetext{
"When the owner decided to alter my employment status from full-timer to part-timer, we talked in a friendly personal atmosphere with her explaining why my employment status should be shifted. Under such more personalized negotiation, I could easily understand the situation. I could accept the decision..." (Participant C, female, part-time).

"It is normal for the teachers, female teachers especially, to come to me and start talking about their personal problem. A female teacher, for example, saw me in my office. She was sad because she had to say goodbye to 'Precious'. She enjoyed working here, she was comfortable, but she had to stay with her husband who had just been assigned to his Jakarta office. Some other female teachers come and talk to me about their family problems; it's just normal and I am happy to be able to be their shoulders to cry on...." (Participant O).
} 
It is interesting to note that tensions between owner and teachers can rise, especially in discussions about pay-rises or in teachers' suggestions of marketing ideas for the school, as quoted in the following piece of interview:

\begin{abstract}
"When we say want a pay rise, the owner says she will grant it when the number of students significantly goes up. When we give her some ideas for marketing to help elevate the number of students, she does not seem to listen..." (Participant G, male, full-time).
\end{abstract}

Armstrong (2009, p 1950) added to the view that the management must communicate with the staff about organization policies and strategies. Furthermore, employees must be given the chance to comment and react to policies that deal with business strategies, wages, work requirements, and development programs. Although communications between the teachers and the owner at 'Precious' are not always satisfactory to both parties, the positive side tends to prevail.

\title{
Work environment and workplace well-being
}

Each of the organization's five buildings are characterized by a two-story construction and a wellmaintained garden in the center of the first floor. There is an almost identical architectural style across the buildings. Classrooms are air-conditioned and audio equipment in the rooms has been adjusted to the need of advanced technology; compact discs are no longer in use, having been replaced by digital devices controlled by tablets operated with Bluetooth connection. Free WIFI is also provided. The work environment is both physically and psychologically perceived by teachers as comfortable and pleasant, as detailed in the following quote:

"The workplace environment here has been comfortable and convenient with relatively complete facilities. We even have a garden here and, with greeneries. I like spending my time working or just relaxing here. Sometimes I don't want to go back to my boarding house; I just stay here. It's comfortable" (Participant F, male, full-time).

The fact that a physically and emotionally comfortable work environment is highly significant in employee retention was affirmed by Horwitz et al. (2003) who stated that a workplace should be a pleasant place in which to work if a high level of employee retention is to be achieved. He stated that a stimulating work environment is one where there is a pleasant working experience, the resources are adequate, and there is some degree of flexibility.

\section{Leadership}

At 'Precious', leadership demonstrated by the Principal (head of school for academic affairs) is more extensively perceived when compared to the central leadership (owner) and Director of Studies. This is because the Principal is a direct super-ordinate who supervises the teachers daily. As the teaching operation manager, the Principal's roles include the responsibility for distribution of teaching assignments, the making of the teaching schedule, peer-observation plan, assurance and maintenance of course files, and to resolve other teaching issues. The Principal is who junior teachers go to when they require help in issues regarding teaching quality improvement. The following quotation shows how the Principal's leadership has been perceived as beneficial for the day-to-day teaching process:

\footnotetext{
"Each term we are assigned to new classes. The Principal writes the class scheduling; who teaches which class. He also sets up the plan for peer-observation and workshops. Some of the teachers rely on him when they get stuck with teaching ideas or have problem with teaching topic mastery. We can say that we depend on him in many things and he never disappoints us" (Participant E, female, part-time).
}

One study emphasizes the importance of supportive quality supervision for employees, and this is in line with the way in which the Principal performs his duties at 'Precious' (Ellett et al. 2007). Similarly, Joo (2010) is of the view that it is important to provide supportive supervision to top employees and Eisenberger et al. (2002) found that the feeling of being supported by the manager, rather than by the organization, is more important for building employee retention. 


\section{Training and career development}

Prior to taking on any teaching assignments, newly recruited teachers were required to undergo an initial training lasting three months to consolidate their introduction to the specially designed teaching techniques and delivery of communicative English practice at 'Precious'. Apart from the initial training provided to new teachers, 'Precious' also offers workshops three to four times in one term. Attending to such workshops is not compulsory but offer the chance for the teachers to enhance their existing knowledge and receive updates on classroom activities and teaching ideas.

"There is the time when both the teachers and students get bored with how classroom activities are
done. Weneed related fresh ideas every now and then. Workshops are important as they help teachers
get updated with new classroom ideas and learning atmosphere..." (Participant A, male, full-time).

In regard to this, a study by Swanson \& Holton III (2009, p 441) explained that workshops serve as competence-based training that significantly help employees in a rapidly changing society. This competence-based training is perceived as the best way to increase and update the knowledge an employee has regarding the organization he or she is based in. There are no clearly defined organizational career development schemes at 'Precious'. The training and workshops offered are instead beneficial for individuals in the sense that they provide useful teaching knowledge that can be used both inside the organization, and if the employees so wish, outside of 'Precious' too.

\section{Organizational policies, procedures, and systems}

The employment policies and systems that 'Precious' has to offer are perceived as convenient by the teachers. The full-time and part-time employment scheme has proven to be favorable as it extends to some level of time flexibility. The following interview extract shows how the flexibility is perceived by one of the teachers:

\footnotetext{
"Flexible working time really matters here. There is no work as comfortable as the one that offers working time flexibility. You see, I work here at 'Precious' and I have another business, a kind of business other than teaching that I can do outside my teaching schedule at 'Precious' (Participant $\mathrm{H}$, male, part-time).
}

The flexibility with timings means the teachers are more likely to be happy staying at 'Precious'. Research has stated that organizational flexible policies have a considerable positive impact to employee engagement (Devi 2009).

\section{Work culture}

There has been a specially shaped work culture at 'Precious' since its conception over 30 years ago. The work culture has been molded by the owner's husband Mr. Good (name changed for privacy purposes) and the culture is represented in the way the teachers maintain a high punctuality, good teaching preparation, and consistent quality teaching.

The owner and her husband were determined to reinforce punctuality and discipline from the start in order to tackle bad workforce habits and half-hearted commitment. As time went by, the work culture was shaped to the pleasant culture it is now, and it has become a solid aspect of the work environment at 'Precious'. The is highlighted by the Owner, as quoted below:

"With regards to punctuality and discipline, Mr. Good is really strict. On the first months of our school operation, he would be very angry when a teacher failed to start a class on time or if they came into class without proper teaching preparation. He would stand in the corridor and watch and make sure teachers come into and leave class on time. He would bang the table if teachers failed to demonstrate high level of discipline. As time went by, all the teachers became more and more punctual and disciplined, with a high level of commitment. The expected work culture is there now, and Mr. Good is very proud to see that the local teachers can make it" (Participant O). 
According to one study (Armstrong 2009), the values and norms that shape culture are formed in four ways. Firstly, values are shaped by the leaders of the organization, especially those who have intentionally shaped them in the past. Secondly, by the emergence of critical incidents, or in other words, important events that result in the understanding of good and bad conducts. Thirdly, by the need for implementation of effective work relations among organization's members that construct values and expectations. Fourthly, in the fact that culture is influenced by the organizational environment. The following interview extract confirms this approach has been implemented at 'Precious':

\begin{abstract}
"Mr Good never failed to give us example or set himself as an example, sometimes by means of role modelling in many cases. And it was simply implanted in our minds..." (Participant H, male, part-time).

"Punctuality and good teaching preparation is in our blood now. You don't feel comfortable nor happy when you are late for a class or when you come into class without good preparation..." (Participant C, female, part-time).
\end{abstract}

The organizational culture has formed a strong local teacher engagement at 'Precious'. In the view of Nichol (2015), employee engagement is a direct result of strong organizational culture. The stronger the organizational culture, the better the employee's understanding will be of what to expect from the institution. Engaged employees will stay happily in an organization where they are able to develop motivation and commitment.

\title{
Psychological contract
}

The teachers are happy and proud to work at 'Precious' for a number of reasons. Some of these reasons have emotional factors, that include having pride for the organization's long-established good reputation, the distinguished teaching-learning method, working time flexibility, and personal teaching skills and competence development. Other reasons include alternate incomes, the stimulating work environment and the supportive relations with co-workers. This explains why many of the teachers are passionate about the organization and wish to stay there, despite potential offers of employment from different organizations that offer a more attractive financial benefit, as confirmed in the following interview extract:

\footnotetext{
"I've been working in 'Precious' for 23 years and have never wanted to leave. I have never been interested in the offers from similar training institutions, nor tried to find better experience in other related jobs other than teaching English. I am doing fine here. This is where I belong to. During week-days I work; teaching classes, helping other teachers, creating course-files and on week-ends sometimes I go back to my hometown or just stay in my boarding house or here in 'Precious'..." (Participant F, male, full-time).
}

In this sense, employee retention and engagement can be linked to the concept of psychological contract. According to Armstrong (2009), psychological contract is a set of unwritten expectations between the employees and employer that form two elements for the making of employee engagement; (1) the rational aspect of the employee's understanding of their role's alignment to the interest of the organization and how such a role is adjusted to the business goals, and (2) the employee's feelings about their organization and the job and how they provide a sense of personal accomplishment. Psychological contract creates attitudes and emotions that shape and influence implicit and dynamic behavior through development and changes.

Psychological aspects that support employee retention are also recognized by Luthans (2012) who forwarded four psychological concepts included in what he named psychological capital (PsyCap) These four concepts are as follows: 1) Efficacy, one's belief that he/she has the ability to perform a job. 2) Optimism, a demonstration of positive strength that includes emotion and positive motivation. 3) Hope, the willingness to be successful and the ability to lead the path to such success. 4) Resilience, the ability to resist difficult situations and to stand back up after a fall. 
The fact that non-financial rewards can hold more significance than financial rewards helps us to understand how employee retention has been formed at 'Precious'. With regards to this, George (2014) was of the view that professional workers are more likely to stay in organizations where the management style is deemed appropriate, where the working experience is pleasant, where resources are adequate, where there is a degree of flexibility, where people feel part of a team with friendly and caring colleagues who are available, and where there is the opportunity to learn new skills or to obtain promotion.

\section{Conclusion}

Employee retention at the 'Precious' English language course was not intentionally designed in the official employee retention strategies at the time the organization was established more than 30 years ago. The employee retention has been the result of a natural retention process constructed by employee engagement in response to the need to maintain the distinguished teaching method, good teaching preparation, and established work culture.

Some factors found at 'Precious' are considered to have shaped the organization's employee retention, namely the work challenges, the opportunity to learn, positive relations with co-workers, work-life balance, good communications, a stimulating work environment, training and workshops, the organization's policies, work culture, and psychological contract. It is the non-financial reward aspects that predominantly form the high rate of employee engagement and job satisfaction that in turn contributes to employee retention at 'Precious'.

This research can serve as an initial reference on employee retention in middle-sized firms with fulltime and part-time employment schemes. This kind of research can also be carried out to explore employee retention and employee engagement in organizations which employ workers with different professional backgrounds.

\section{References}

Aguenza BB \& Som APS (2012) Motivational factors of employee retention and engagement in organizations. International Journal of Advances in Management and Economics 1 (6).

Anitha J (2014) Determinants of employee engagement and their impact on employee performance. International Journal of Productivity and Performance Management 63 (3):308-323.

Armstrong M (2009) Armstrong's Handbook of Human Resource Management Practice $\left(11^{\text {th }}\right.$ edition). London: Kogan Page.

Bandura RP \& Lyons PR (2014) Situation-vacant fall where employees are engaged: Involvement boosts various aspects of organizational performance. Human Resources Management International Digest 22 (5):22-25.

Das BL \& Baruah M (2013) Employee retention: A review of literature. Journal of Business and Management 14 (2).

Deery M \& Jago L (2015) Revisiting talent management, work-life balance and retention strategies. International Journal of Comtemporary Hospitality Management 27 (3):453-472.

Devi VR (2009) Employee engagement is a two-way street. Human Resource Management International Digest 17 (2):3-4.

Eisenberger R, Stinglhamber F, Vandenberghe, C, Sucharski IL \& Rhoades L (2002) Perceived supervisor support: Contribution to perceived organizational support and employee retention. Journal of Applied Psychology 87 (3):565.

Ellet AJ, Ellis JI, Westbrook TM, \& Dews D (2007) A qualitative study of 369 child welfare professional perspectives about factors contributing to eomployee retention and turnover. Children and Youth Service Review 20 (2):264-281. 
George C (2014) Retaining professional workers: What makes them stay?. Employee Relations 27 (1):s102-121.

Govaerts N, Kyndt E, Dochy F, \& Baert H (2011) Influence of learning and working climate on the retention of talented employees. Journal of Workplace Learning 23 (1):5-55.

Horwitz FM, Heng CT, \& Quazi HA (2003) Finders, keepers? Attracting, motivating and retaining knowledge workers. Human Resource Management Journal 13 (4):23-44.

Hughes JC \& Rog E (2008) Talent management: A strategy for improving employee recruitment, retention and engagement within hospitality organizations. International Journal of Contemporary Hospitality Management 20 (7): 743-757.

Hyman J \& Summers J (2004) Lacking balance? Work-life employment practice in the modern economy. Personnel Review 33:418-4129.

Joo BKB (2010). Organizational commitment for knowledge workers: The roles of perceived organizational learning culture, leader-member exchange quality, and turnover intention. Human Resources Development Quarterly 21 (1):69-85.

Khan WA (1990) Psychological conditions of personal engagement and disengagement at work. Academy of Management Journal 33 (4):692-724.

Luthans F (2011) Organization Behavior: An Evidence-based Approach. New York: MacGraw HillIrwin.

Nichol J (2015) How company culture affects employee engagement?. Culture IQ. [Accessed 5 November 2018]. https://cultureiq.com/employee-engagement-company-culture/.

Raco JR (2010) Metode Penelitian Kualitatif. Jakarta: PT Gramedia Widiasarana.

Saebani BA (2015) Filsafat Ilmu dan Metode Penelitian. Bandung: Penerbit Pustaka Setia.

Swanson RA \& Holton III EF (2009) Foundations of Human Resource Development (2 ${ }^{\text {nd }}$ ed.). San Francisco: Berret-Kohler Publishers, Inc.

Thomas D (2010) Failure to retain talent costs UK firms $£ 42$ billion, says PwC. [Accessed 25 April 2017]. http://www.personneltoday.com/hr/failure-to-retain-talent-costs-uk-firms-42-billionsays-pwc/.

Tymon Jr WG, Stumpf SA, \& Smith RR (2011) Manager support predicts turnover of professionals in India. Career Development International 16 (3):293-312.

Walker JW (2001) Zero defection. Human Resource Planning 24 (1):6-8. 